\title{
Contribution of traditional fermented foods to food systems transformation: value addition and inclusive entrepreneurship
}

\author{
Valentina C Materia ${ }^{1}$ • Anita R Linnemann ${ }^{2}$ - Eddy J Smid ${ }^{3}$ - Sijmen E Schoustra ${ }^{4,5}$ (D)
}

Received: 16 March 2021 / Accepted: 11 June 2021 / Published online: 9 July 2021

(C) The Author(s) 2021

\begin{abstract}
To date, many efforts to eradicate hunger include increasing agricultural production, processing of raw materials and supplementation, and fortification of foods. Locally produced foods represent a significant part of Food Systems as they contribute to tackling hunger and malnutrition. However, few studies have investigated the processing of traditional fermented foods at household level as a means to improve nutrition and triggering inclusive entrepreneurship, two crucial dimensions Food Systems build on. Fermentation is an ancient processing technique that relies on transformation of raw materials by microbial activity and is mainly undertaken by women. This paper posits that upscaling small scale fermented food processing activities while enhancing functional food properties and fostering women entrepreneurship contributes to prevention of food losses, promotion of nutrition and health, and entrepreneurial opportunities for current processors. This is key for effective policy interventions to foster food security in challenging contexts. - .
\end{abstract}

Keywords Nutrition and health · Food losses · Sub-Saharan Africa · Food processing $\cdot$ Livelihoods $\cdot$ Gender $\cdot$ Inclusive entrepreneurship

\section{Introduction}

Many efforts to eradicate hunger focus on a Food Systems Approach (FSA) (Berkum et al., 2018; GlobalPanel, 2016; HLPE, 2017; UNEP, 2016). Efforts include increasing agricultural production, various levels of processing of raw materials and supplementation, and fortification of foods to combat micronutrient deficiencies (Keding et al., 2013). The supply of nutritionally adequate foods to the global population is still

Sijmen E Schoustra

sijmen.schoustra@wur.nl

1 Department of Social Sciences, Business Management and Organisation group, Wageningen University and Research, 6707KN, Wageningen, The Netherlands

2 Department of AFSG, Food Quality and Design, Wageningen University and Research, 6700AA, Wageningen, Netherlands

3 AFSG, Food Microbiology, Wageningen University and Research, 6700AA, Wageningen, The Netherlands

4 Department of Plant Sciences, Laboratory of Genetics, Wageningen University and Research, 6700AA, Wageningen, The Netherlands

5 Department of Food Science and Nutrition, School of Agricultural Sciences, University of Zambia, Lusaka, Zambia challenging though, which represents a threat to food security. Local foods - defined as foods that are produced and/or processed at small distance where they are consumed (Waltz, 2010) - represent a significant part of food systems: rural and urban communities in many developing countries depend on endogenous locally available plant and animal resources that are available in the immediate environment (Chadare et al., 2018). Moreover, local foods are embedded in the culture of local populations, which for generations have shaped practices, knowledge systems and decision-making processes around the cultivation and preparation of indigenous food resources (Kuhnlein et al., 2009). Yet, the importance of local foods to local populations and the important position in their diets has not been reflected in local foods being the focus of large-scale programs to eradicate hunger and to promote nutrition and livelihoods. In this paper, we discuss in particular local traditional fermented foods. Despite their contribution to tackling hunger and malnutrition (Chileshe et al., 2020a; Chileshe et al., 2020b; Egounlety et al., 2002), few studies have investigated the evolution of processing of fermented foods at household level as a means for value addition and nutrition, while at the same time triggering inclusive entrepreneurship, two crucial dimensions on which food systems are based (Berkum et al., 2018). 
Among processed local foods, traditional fermented foods are a special category, having been an important part of the human diet in nearly every culture on every continent since the start of civilization (Hesseltine and Wang, 1967; Tamang et al., 2020). Through transformation by a diverse community of microbes of raw materials including cereals, milk, beans and meat or fish, value is added, which includes prolonged shelf-life, improved taste, increased nutritional value, health benefits and increased commercial value (Aworh, 2008; Battcock and Azam-Ali, 1998b; Kort and Sybesma, 2012; Marshall and Mejia, 2011b; Tamang et al., 2020). Traditional fermentation helps prevent food losses and extends shelf-life of raw materials, which can increase seasonal food availability and the range of food options available to individuals (Keding et al., 2013) also in difficult times, in high-risk climate and in conflict areas (Marshall and Mejia, 2011a). Therefore fermented foods offer advantages to both sellers and consumers by improving diets and health, thus contributing to local food security and livelihoods (Battcock and Azam-Ali, 1998b; FAO and WHO, 1996; Marshall and Mejia, 2011a).

Mainly processed at the micro and small-scale of household level (Anukam and Reid, 2009; FAO and WHO, 1996), food fermentation represents an important economic opportunity in particular for women and the marginalized (Battcock and Azam-Ali, 1998b; FAO and WHO, 1996; Marshall and Mejia, 2011a). Entry barriers are low, start-up costs are low, no possession of particular assets is required, and fermentation is combinable with domestic responsibilities. With appropriate access to inputs, knowledge and education (Keding et al., 2013), fermentation activities can allow the most marginalized in society to contribute to the food security of their families and communities, and increase their independence through generation of income (Marshall and Mejia, 2011a; Materia et al., 2021). The global popularity of fermented foods exemplifies the opportunities for (traditional) fermentation to become a diversification enterprise. Well known (Western) examples of "artisanal" fermented products that are now produced at large/ industrial scale include beer made by microbreweries and French cheese like Roquefort made from raw milk. As economic activity, fermentation has in fact potential in providing a diversified stream of income for a rural household. Although for several well-known fermented products - such as yoghurt, cheese, beer and wine - the process has been industrialized, the traditional ones (thus, those whose processing has not been formalized, standardized nor upscaled to an industrial scale) maintain important cultural values that consumers want to preserve and restore, being considered part of the national heritage of a country (Aworh, 2008; Battcock and Azam-Ali, 1998b; Elberi and Lee, 2011; Fellows and Hilmi, 2011; Holzapfel, 2002; Rampa et al., 2020). The indigenous knowledge of producing them is an integral component of many cultures (Aworh, 2008; Rampa et al., 2020).

In this contribution we focus on two concrete aspects of fermented foods, the first is value addition to raw materials and prevention of food losses and the second is entrepreneurial opportunities for current traditional processors. This is part of a multi- disciplinary approach to highlight the opportunity for research and policy to focus on traditional fermented foods to help mitigate food insecurity and malnutrition. Currently, processing processes of traditional fermentation have mostly not been standardized nor formalized due to lack of documented knowledge and process formalization and optimization. For standardization and subsequently formalization, product group specific evidence is needed on nutritional benefits and functional properties that lead to value addition to raw materials to base interventions in support of local traditional food processing. Even though local and traditional foods are often more or equally nutritious and microbiologically safe as their global counterparts, these functional properties have often not been measured, limiting inclusion of such local foods in interventions or policy to promote food security (Chileshe et al., 2020a; Rampa et al., 2020).

Entrepreneurial opportunities are currently hampered by the lack of effective value chains, which often prevents highly nutritious local traditional products from meeting consumers' needs and from reaching a wide range of consumers in both informal and formal markets. Addressing the problem of food distribution, diversity, consumption and commercialization through active engagement of the informal sector represents an effective strategy to strengthen livelihoods for the (urban) poor (Patel et al., 2014). We advocate to put small local processors (usually, women working in informal settings) at the center stage of food systems' transformations when exploiting the tremendous entrepreneurial potential of traditional fermented foods. We argue that the industrial upscaling of traditional fermented foods leaves current traditional processors behind, impeding long-term development of the rural poor. Generating, identifying and exploiting business opportunities related to traditional fermentation in rural areas provides incentives for especially women to build their future there rather than migrating to larger urban areas (Aworh, 2008; Marshall and Mejia, 2011a). This mitigates the pressure on rapidly growing cities and facilitates modern development and better infrastructure in rural areas - which are among the drivers for the transformation of food systems globally.

This contribution builds on recent evidence collected on various milk and cereal-based traditional fermented foods produced in Africa, representative of many traditional fermented foods in the continent. Specifically, we focus the contribution towards two key food system components, namely prevention of food losses and enhancement of nutrition as well as inclusive entrepreneurship.

\section{Traditional fermentation: Value addition and entrepreneurial opportunities}

In most cases, traditional fermented foods are processed at household level for home consumption using locally available raw materials. Excess product is sold at local markets by some 
processors, and a small fraction of processors may specifically process for sales. Most fermented foods are acidic, some are alcoholic. Processing typically starts by pre-processing raw materials (Nout et al., 2007). In the case of cereals as raw material, these may be grinded and mixed with water, and then heated and boiled for some time. Raw milk may be checked for quality using simple tests and be sieved to eliminate large particles. The preprocessed raw materials are then placed in a fermentation vessel, usually a plastic container, metal can or calabash, and kept at ambient temperature. Fermentation vessels may be re-used between fermentation cycles. In this way, part of the microbial consortium underlying the fermentation is transferred to fresh raw material to kick-start a new round of fermentation. This processes is called backslopping (Holzapfel, 2002). A typical batch volume is around 5 to 201 and fermentation typically takes between 24 and $48 \mathrm{~h}$ to finish. After this time, levels of acid and/ or alcohol formation arrest the growth of all microbes. In most cases, final products are obtained right after fermentation ends. In some cases, some post processing occurs, for instance the mixing with other foods. Most foods are consumed within the household and/or sold at informal markets in the hours or at most days after fermentation ends.

In this contribution, we highlight various traditional fermented foods as archetypical examples, Mabisi and Munkoyo from Zambia, Mahewu from Zimbabwe and Akpan from Benin (Madode et al., 2005; Moonga et al., 2019; Phiri, 2019; Pswarayi and Gänzle, 2019). See Appendix for a full description, Fig. 1 for an illustration with pictures and Table 1 for some key features of these foods. All are acidic products consumed by both men and women of all age groups, and cover a range in level at which traditional knowledge has been documented - which is a first step towards formalization - and in involvement of (institutional) actors. They share the properties that fermentation is by a diverse (and uncontrolled) community of fermenting microbes (Nout et al., 2005), the process has not been formalized and is performed at household level by small-scale processors (Holzapfel, 2002). Mabisi is based on raw milk. After sieving, raw milk is placed in a fermentation vessel where fermentation takes place at ambient temperature. After around 24 to $48 \mathrm{~h}$, a mildly sour product is derived. Slight variations in processing exist, yielding a range of Mabisi types (Moonga, 2019; Moonga et al., 2020b). Munkoyo, Mahewu and Akpan are cereal based, using mainly maize, sorghum and/or millet. After milling the cereal, they are mixed with water and boiled for at least one hour to allow for gelatinization of starch, after which the mixture is allowed to cool. In the case of Munkoyo, Rhynchosia roots are added to provide the microbial inoculum and enzymes to degrade complex carbohydrates (Moonga et al., 2020a; Phiri, 2019). For Mahewu and Akpan, malted grains or flour are added as source of microbial inoculum and enzymes (Madode et al., 2005; Pswarayi and Gänzle, 2019). Then, the mixtures are placed in vessels where fermentation takes place for around $48 \mathrm{~h}$ at ambient temperatures. For Munkoyo and Mahewu, the process is complete after the fermentation step. For Akpan, the fermented mix is cooked, after which milk and an uncooked fermented mix is added to taste right before consumption (Madode et al., 2005).

\subsection{Capitalizing on value addition to raw materials through traditional fermentation}

Value addition to raw materials through fermentation presents at least four unique properties, which distinguish them from
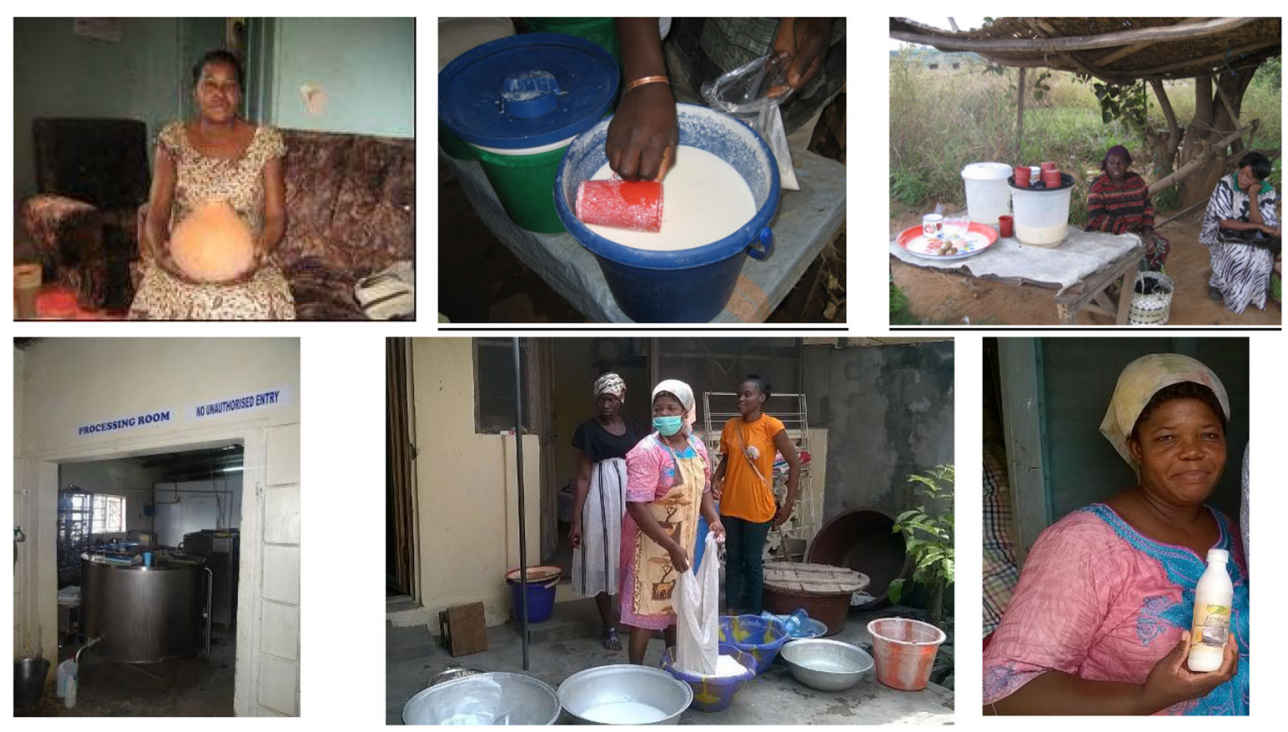

Fig. 1 Current practice. Traditional processor holding a calabash and sellers of traditionally processed milk (Mabisi) at selling at local markets (top three pictures) in Zambia. In recent years, smallholder farmers have formed cooperatives where raw milk is collected and, in some cases,

processed to Mabisi (bottom row left picture) and sold at small scale directly from the cooperative or through local outlets. Akpan processors in Benin have started to package their product for sales at local supermarkets (bottow row middle and right picture) 
Table 1 Key features of traditional fermented foods Mabisi, Akpan and Mahewu when processed in a traditional way

\begin{tabular}{|c|c|c|c|}
\hline $\begin{array}{l}\text { Fermented food } \\
\text { Feature }\end{array}$ & Mabisi & Akpan & Mahewu \\
\hline Main country of origin & Zambia & Benin & Zimbabwe \\
\hline Raw materials & Raw milk & $\begin{array}{l}\text { Cereal (maize, sorghum, millet), fresh } \\
\text { milk to taste }\end{array}$ & Cereal (maize, millet) \\
\hline $\begin{array}{l}\text { Time needed for processing from raw material } \\
\text { to final product }\end{array}$ & Around one to two days & Around two to three days & Around two days \\
\hline Shelf life without refrigeration & Around three days & Around three days & Around four days \\
\hline Typical batch size & 51 & 101 & 101 \\
\hline Processing by & Women & Women & Women \\
\hline Urban or rural & $\begin{array}{l}\text { Rural, where raw milk is available } \\
\text { from cattle }\end{array}$ & $\begin{array}{l}\text { Both urban and rural, sales more in } \\
\text { urban areas }\end{array}$ & $\begin{array}{l}\text { Mainly rural, increasingly } \\
\text { also urban }\end{array}$ \\
\hline Price per serving $(200 \mathrm{ml})$ & 0.35 EUR & 0.20 EUR & 0.20 EUR \\
\hline
\end{tabular}

other foods in the human diet (Nout et al., 2005): (1) increased shelf-life and preservation of raw materials, (2) improved taste and other organoleptic properties, (3) increased nutritional value and (4) health benefits to their consumers (Kort and Sybesma, 2012; Nout et al., 2005). These properties are the result of microbial activity underlying the fermentation process. In traditional fermented foods, the microbial communities that drive fermentation are more diverse than most industrially fermented foods: microbial communities in traditional fermentation consists of many (over ten) species, where industrial fermentation relies typically relies on one to three species (Katz, 2016). For various traditional fermented foods, including for Mabisi, Munkoyo, Mahewu and Akpan, industrial versions exist, most of which relying on a fermentation with sterilized raw material and single or just a few microbial strains for ease of processing, yet that lack the full aroma and functionality of the traditional versions.

The first benefit, that fermentation can remove food-borne pathogens from raw materials, is due to increased acidity and/ or presence of alcohol after fermentation, which inhibits growth of spoilage organisms and prolongs the shelf-life of the raw materials after processing. This results in a product with enhanced microbiological safety compared to raw materials (Nout et al., 2007; Nout et al., 2005). In addition, fermenting microbes may excrete various compounds, such as bacteriocins, that specifically inhibit pathogenic bacteria (Nout et al., 2005). This is particularly of interest for perishable raw materials such as raw milk, where fermentation can help reduce food losses.

For Mabisi, we have demonstrated that the transformation of raw milk into the final product is very robust in terms of microbiological safety. Using standard protocols inspired from the European Food Safety Authority (Regulation (EC) No 853/2004), experimental work demonstrated that during traditional processing proliferation of various relevant pathogens, such as Salmonella, Staphylococcus aureus and Listeria monocytogenes, was reduced to acceptable levels (Van der Zon, 2019). This even was the case when milk was used that had been rejected at milk collection centres due to low quality raw milk. Further, the shelf-life of traditional Mabisi is around one week without refrigeration (Moonga et al., 2020a). Since processing of many traditional fermented foods, including Munkoyo, Mahewu and Akpan, relies on similar fermentation properties with respect to microbial ecology, we expect similar levels of microbiological safety for these foods.

The second benefit, a richer taste and improved organoleptic properties of the raw materials, is due to the production of flavour compounds by the fermenting microbes (Thierry et al., 2015). This commonly increases the commercial value of the raw materials, providing opportunities to improve livelihoods of its producers due to opportunities of sales. Diverse microbial communities commonly generate more diverse aroma profiles (Erkus O et al., 2013; Phiri et al., 2019; Thierry et al., 2015), suggesting that traditionally fermented foods have a richer taste pallet than most industrially produced fermented foods. For Mabisi, a commercial variant exist, called lacto-Mabisi, which is made using a defined mix of two bacterial strains in sterile milk. When asked, consumers identified the traditional version of Mabisi more attractive in taste $(85 \%$ of respondents in middle-class urban areas; (Van de Ven, 2018)). Small scale interviews on Mahewu, Munkoyo and Akpan suggest the same sensorial preference for traditional fermented foods over similar industrial versions.

The third benefit of fermentation, the increase of nutritional value of raw materials, is due to the action of microorganisms which make food components become better available in the human digestive tract. For instance, complex carbohydrates may become pre-digested and bio-availability of key micronutrients like iron and zinc may be increased (Marco et al., 2017; Nout et al., 2005). Anti-nutritional factors in raw materials such as phytate may be degraded by the fermenting microbes, which is relevant for many cereal based 
foods including Munkoyo, Mahewu and Akpan. Microbes can also add micronutrients, they can for instance synthesise essential B-vitamins, nutritionally enriching raw materials (Wolkers-Rooijackers et al., 2018).

The increased nutritional value helps to enhance diet quality in diets low in (bio)available micro-nutrients and rich in anti-nutritional factors. For Mabisi and Munkoyo, a modelling tool (Optifood) was used to assess the nutritional impact of the consumption of these traditional foods (Chileshe et al., 2020a). The model revealed that addition of traditional Mabisi and Munkoyo to current diets results in adequacy for various minerals and B-vitamins (Chileshe et al., 2020a). For Mabisi, adequacy was also achieved for fat and protein. These B-vitamins are produced through various metabolic pathways of interacting fermenting microbes - these could be the focus of future research for further elucidation (Chileshe, 2019). Given that other traditional fermented foods like Mahewu and Akpan have similar fermenting microbial consortia, we expect similar B-vitamin enrichment and other nutritional properties (Smid and Hugenholtz, 2010).

The fourth benefit, promotion of health benefits to consumers, is due to the modulation of the gut microbiota through its exposure to live lactic acid bacteria (probiotics) and their metabolites. This results in shifts to healthier composition in the gut microbiota, which can help prevent colonization of pathogenic microbes and may stimulate the immune system of its consumers (Kort and Sybesma, 2012). Specifically for Mabisi and Munkoyo, in vitro studies generated evidence showing that consumption of Mabisi and Mahewu leads to a shift in the gut microbiota to consist of higher proportions of lactic acid bacteria indicative of a healthier species composition (Chileshe, 2019). The overall metabolism of the gut microbiota also shifted to contain higher levels of short chain fatty acids, which is suggest to have health benefits (Morrison and Preston, 2016). These health benefits are especially relevant for undernourished populations, since these more regularly suffer from disease linked to dysbiosis in the gut microbiota (Marco et al., 2017).

Traditional processing should be upscaled to reach a wider share of consumers. To maximize the beneficial functional properties, a diverse microbial community should be used for fermentation. In most industries, a microbial starter of only one or two strains is most commonly used since this makes the processing more reproducible with respect to product properties, since a single strain fermentation is easier to control which is a key feature in most industrial fermentations - then a fermentation with a mix of microbes. The diverse nature of the microbial community in traditional fermentation has a higher potential to maximize the four benefits, because of higher levels of resilience and more diverse functionality (Butler and O'Dwyer, 2018; Erkus O et al., 2013). Opportunities for upscaling of traditional fermentation rather than upscaling using few microbial strains are feasible. Some examples of industrially made fermented foods using undefined mixed microbial communities, such as sourdough breads made with mixed communities of wild yeasts (Carbonetto et al., 2018). Previous work on Mabisi showed that standardization of processing conditions and procedures results in uniform product properties, even when undefined microbial communities consisting at least 15 different bacterial species were used (Moonga et al., 2020a). Since other traditional foods rely on similar microbial consortia, this most likely also applies to other traditionally fermented foods. This is promising, since higher levels of production can be achieved while maintaining high levels of microbial diversity that promote the unique functional properties of traditional fermented foods. In turn, the specific nutrition and health benefits of consuming traditional fermented foods such as Mabisi, Munkoyo, Mahewu and Akpan can be part of promotion and sensitization campaigns.

\subsection{Entrepreneurial opportunities in processing fermented foods}

In this section, we describe direct benefits of entrepreneurship in traditional fermentation, as well as several barriers and indirect benefits. By reducing post-harvest food losses and increasing availability of nutritious and attractive foods (Aworh, 2008), small scale fermentation activities have intrinsic potential for positive impact on food security and on economic development. In rural areas where most of the raw materials for fermentation are produced, fermentation activities represent a significant entrepreneurial contribution (Taiwo et al., 2002). It generates employment opportunities and helps to reduce rural-urban migration and the associated social problems (Aworh, 2008; Kadirvel et al., 2018; Olagunju et al., 2020; Robson and Gallagher, 1993). Processing of fermented foods involves low capital investment as it relies on traditional technologies and requires low labour inputs. Managing such an enterprise in principle would not require literacy and numeracy if not minimal, providing therefore for more ample inclusiveness (Battcock and Azam-Ali, 1998b; Marshall and Mejia, 2011a; Taiwo et al., 2002). Being highly combinable with a variety of other traditional and domestic activities, processing of traditional fermented foods represent an area dominated by women, with knowledge passed down for generations (Marshall and Mejia, 2011a).

Various direct benefits of entrepreneurial activities in traditional fermentation exist, yet these need to be promoted and scaled to enhance impact. By means of processing of traditional fermented foods women processors contribute to local, national and global food security, economic growth as well as to value addition at the local level (Elberi and Lee, 2011; Ibnouf, 2011; IFAD, 2019). Like for other forms of (informal) employment, the revenue women earn from fermented foods activities can provide for family needs, for 
livelihood, for savings but also serves as safety net in case of shocks. These shocks relate to the women themselves, such as abandonment and widowhood, or to the macro-economic situation, with the case of climate related events or pandemics. In this sense, women exercise a remarkable agency in the food systems through fermented foods (Arslan et al., 2020). Processors are entrepreneurs as they take risks in their decisions on how to balance income-generating activities with everyday work on subsistence (Materia and Dentoni, 2020). Nonetheless, women's contribution to livelihood and food security, specifically through processing of fermented foods, is underestimated as this processing is mainly performed in informal settings (ILO, 2018). As such, no data are available that could quantify and substantiate their potential contribution to livelihood and food security. Official estimates exclude work performed outside formal employment (including activities related to traditional fermentation), and only capture market-oriented employment by this underestimating the extent of rural women's activities (FAO, 2018).

We argue that production and processing of foods like Mabisi, Munkoyo, Mahewu and Akpan offer evident opportunities for fostering inclusive entrepreneurship (Materia et al., 2021; Rampa et al., 2020). Literature confirms that upscaling small scale fermentation is a prerequisite to increase not only economic and social benefits from traditional fermented foods, but also to sustainable development of families and communities (Battcock and Azam-Ali, 1998a; Bell et al., 2017; Marshall and Mejia, 2011a; Rampa et al., 2020). Various barriers exist for local micro and small scale producers to upscale from the current very informal household level. Interviews of around 30 women processors, four focus group discussions with around 10 participants each and two stakeholder meetings with around 40 institutional stakeholders and representatives of farmer cooperatives have been conducted in the context of various research projects on traditional processing led by the Authors in recent years (Schoustra et al., 2018). These have indicated that the environment in which women operate - characterized by often rather unsupportive formal and informal institutions - restrict their personal growth, their decision making, their empowerment (FAO, 2018) (Reid et al., 2020) and their effective contribution to the livelihood of their families and communities by means of fermentation activities.

This leads to various barriers for entrepreneurship, of which we mention four. First, rural women small-scale producers of Mabisi (Zambia) and Mahewu (Zimbabwe) often struggle to (consistently) produce a large enough volume of products that buyers - such as local shops and supermarkets might be interested to buy for re-sale. Even when they manage to generate sufficient volume, they cannot afford the high transaction costs connected to finding a formal market for their produce (e.g. transport costs, price negotiation, standardization of procedures). As a consequence, they only engage in informal markets and very local sales; earning a living is then challenging. Urban women producers of Akpan (Benin) struggle to compete with other small producers of similar products and have to continuously balance between market sales in nearby urban centers and redistribution within their community or household (Materia and Dentoni, 2020).

Second, most fermentation micro and small businesses led by women are underrepresented in associations or cooperatives (Elberi and Lee, 2011), with the consequence of lacking voice and representation to raise awareness and advocate for their needs (FAO, 2018; Mtumbi-Mwansa, 2021). For example, women producing Mabisi and able to access a market often lack opportunities to negotiate better terms of trade for their products, and as they are not affiliated to organizations, they have minimum chances to survive the competition. The bargaining power of women producing fermented foods is in general rather limited: they often face the only option to accept lower prices for their raw material which often they are obliged to sell to industrial processing companies which produce mass products that do not offer the same nutritional and cultural value the traditional ones do.

Third, for Mabisi, Munkoyo, Mahewu, Akpan and traditional fermented products alike, there is need for formal proof of food (microbiological) safety and associated certification of traditional processing by Standards Bureaus. Due to the lack of formal certification, most traditional fermented foods are uniquely sold at informal markets, stressing the need for formal assessment of food safety and the formulation of critical parameters of processing to meet food safety standards (Van der Zon, 2019). This requires a mix of generic research and validation of food safety combined with product specific policy interventions that promote traditional fermented foods and their usage at wider level (Rampa et al., 2020).

Fourth, upscaling of processing requires value chain development which should focus on connecting wishes and needs of consumers to capabilities and aspirations of processors (Busse and Siebert, 2018; Linnemann et al., 2006). Value chain development should further consider the availability of raw materials, institutional context and aspects of logistics that affect the value chain. However, women producing Mabisi, Munkoyo, Mahewu and Akpan face difficulties in benefitting from the participation to value chains. They cannot access resources such as productive assets, finance, education and technology. As a result, they are concentrated in the less profitable stages of the value chain being invisible to any formal interventions (Dohmwirth and Hanisch, 2019; Elberi and Lee, 2011). In this context, logistics within the value chain also require special attention. Some products (such as Mabisi) are uniquely processed in rural areas where the raw material (fresh milk) is available, some are produced both in rural and urban areas (Munkoyo and Mahewu), some mostly in urban 
areas (such as Akpan). In order to reach large groups of urban consumers, logistics of transportation of either the final product or the raw ingredients need to be taken into account. In addition, while the shelf-life of fermented Mabisi is much higher than the shelf-life of raw milk, many fermented foods such as Mabisi require effective and relatively fast logistics to reach (in)formal sales outlets in urban areas, which may be a challenge (Rampa et al., 2020).

Apart from direct benefits and barriers in entrepreneurship in traditional fermentation, the reduction of food losses by preservation of raw materials provides indirect benefits that reach beyond the direct value chain of fermented foods. This is particularly relevant for perishable raw materials. For example, Mabisi processing helps to prevent losses of raw milk. An assessment in 2017 revealed that small-holder farmers lose around half of the raw milk they bring to milk collection centres, since off-takers (commercial dairy companies collecting the milk) fail to collect all milk on time before soilage. In Zambia, this is estimated to amount to around 100 million litres of raw milk annually (Projectteam, 2017; WorldBank, 2011), which could be (partly) salvaged when processed into Mabisi. Further, as an indirect consequence, many smallholder farmers do not milk more than half of their cows due to lack of prospect of selling the milk. Local Mabisi processing, which extends the shelf-life of raw milk from hours to days, can thus not only salvage the value of milk, but will likely also provide incentive to increased production of raw milk.

The monetary value of the processed raw material is higher than the value of raw materials. For the case of Mabisi, rough calculations can be made of what value would be added by combining the effects of reduced losses of raw milk and higher value (net return) of Mabisi over raw milk. Raw milk sells at 4 ZMW per litre (1 EUR $=25 \mathrm{ZMW})$, Mabisi has a market value of around $20 \mathrm{ZMW}$ per litre in informal markets. Processing to Mabisi adds a value of 14 ZMW is added per litre (after subtracting processing costs). Current figures of a raw milk collected at milk collection centres suggest that small-holders annually sell around 100 million litres to industrial processors. Around the same amount of raw milk litres is not picked up and is mostly discarded, which is a significant loss of value. The discarded milk could in principle be processed to Mabisi. This processing of the not-collected raw milk to Mabisi would prevent the loss of this raw milk and further add a value. Not all available cows are milked, milk production could be roughly doubled without (much) altering current agronomic practice. Should this additional raw milk be processed into Mabisi, economic benefits further increase.

\subsection{A possible business case for a traditional fermented milk-based food: Mabisi in Zambia}

The figures presented illustrate that a profitable business case may exist for traditional fermented foods. This motivated a first pilot assessment of a possible business case for Mabisi to highlight the potential for upscaling the current rather informal processing and to enhance inclusive entrepreneurship at the local level (Mtumbi-Mwansa, 2021). This first assessment could inform a larger study and took into account competition from by multinationals currently processing fresh milk bought by farmers into an industrial version of the traditional Mabisi (lacto-Mabisi), which does not meet the expectation of the consumers (Van de Ven, 2018). Consumers would rather buy the traditional product they were used to consume since childhood in their village and that they generally trust as safe. They are not aware of the nutritional properties it has though, and highlight that the traditional Mabisi is unavailable outside rural areas of milk production (Van de Ven, 2018). This presents concrete entrepreneurial opportunities for upscaling the traditional production of Mabisi. Applying a bottom up approach based on desk research, two focus group discussions with eight processors each, around ten individual interviews at dairy cooperatives in Southern Zambia and a stakeholders workshop with 25 participants in Lusaka representing five dairy cooperatives and several regulators, the study has mapped current production and marketing potential of traditional Mabisi and the connected barriers and issues for its upscaling. The triple layers business model canvas tool has been applied (Joyce et al., 2015), delving attention into the economic, environmental and social aspects of upscaling the traditional Mabisi. With this approach, some possible scenarios to enhance (women) entrepreneurship while upscaling traditional Mabisi were sketched, which inform possible routes policy.

The producers of Mabisi are mainly women farmers (in micro-business activities) who produce at home with limited equipment either for self-consumption or to sell locally. They either use their own fresh milk or buy fresh milk from other farmers (when they do not possess cows on their farms) and ferment it to produce Mabisi in a traditional manner and sell at informal local markets. The volumes of milk that can be collected from cows varies according to seasons (high- or offpeak seasons depending on rainfall), therefore a first barrier is to guarantee a steady supply. Barriers at production level are several: no legal standard of procedures is present, no certification scheme is applied, and no packaging nor label is currently applied to their traditional product. The reason for a lack of legal standardization is that the law prohibits the use of nonpasteurised milk for producing and selling dairy products, which makes this activity rather informal and far from being certified. In principle the use of raw milk could be overcome, as for instance has been done for the use of raw milk to process 
various Roquefort cheeses in France where boundaries for microbiological safety have been defined. The governing body in Zambia (Zambia Bureau of Standards) could similarly decide to allow for the use of raw milk in Mabisi processing.

The market is rather open, very fragmented and inconsistent, although with high growth potential. This brings to the discussion over if and how to render Mabisi more formalized. Different possible scenarios exist for upscaling of traditional Mabisi processing. In order to transform Mabisi into an opportunity for sustaining livelihood to trigger women entrepreneurship, upscaling should be centred around current traditional processors. Rather than asking large industrial parties to start processing traditional Mabisi, involving local processor dairy cooperatives. In the literature, this proves to enhance women empowerment (Mwambi et al., 2020a; Mwambi et al., 2020b), and similarly seems to be more conducive to support entrepreneurship in the traditional Mabisi sector. When these cooperatives would start producing Mabisi and sell it to the market using the channels already adopted for Mabisi (e.g. onsite, kiosks, corner shops), this would guarantee a stable supply system and more standard procedures to get to more formal market. When more farmers sell their milk to the cooperative, the volumes needed would be guaranteed regardless of the high- or off-peak season. Moreover, the cooperative would enhance farmers' skills and competences by means of providing training (e.g. on safety standards, packaging) and supporting their development. This could open franchising opportunities such as anchor enterprises able to manage the establishment of Mabisi production centers in different provinces too. It would be the first step to build capacity for many women who are currently producing in isolation. In this way, farmers could find their own opportunities producing in a more professional way and using the same channels the cooperative would use to sell their products. More generally, this represents a viable opportunity for women to be active and more visible in the system. Belonging to a cooperative would also enhance women bargaining power. This opportunity would help more farmers to sell their milk to the cooperative producing traditional Mabisi than not to the multinationals offering rather low prices for the same raw material.

Although promising, this scenario would require some actions. Existing cooperatives would perhaps not afford to take up this role as they are currently only interested in collecting milk rather than processing it. Focus group discussions, interviews and meeting with stakeholders revealed that a better solution would be to create new cooperatives. However, a policy dialog is needed: more evidence of the nutritional properties of Mabisi is needed to brand the Mabisi in this way produced as nutrition other than only tradition. More standardization of procedures is needed to ensure consistency of product quality, and certification of traditional processing is required for legal sales outside the (very) informal markets. Further, investments and capital are needed to enable further upscaling and to ensure continuity. Finally, a campaign to promote consumption is needed that proves that other than tradition and culture, nutrition and contribution to livelihood are key attributes of the traditional fermented food.

\section{The way forward for traditional fermented foods in food systems transformation}

The evidence provided in this paper on value addition and inclusive entrepreneurship indicates two main aspects need to be addressed to capitalize on the potential of traditional fermented foods for food systems transformation. First, although these foods are still informal products, research should be expanded on validating key aspects of production and consumption. Both generic and product specific evidence is needed on these products' health benefits, to set standards for food safety parameters and to seek formal approval to use traditional way of processing on both formal and informal markets.

Second, although potential for entrepreneurship is evident, the main challenge at the policy level is to guarantee that women processors remain at the centre stage and in control of the value chain. This implies a discussion on what this would imply for (in)formality of production, level of organization and sales. The section below further elaborates on why and how to implement policy in local food systems and value chains with a focus on current women processors and links to the formal market.

\subsection{Potential for policy interventions to keep women processors at the Centre stage}

In order to put smaller producers at the centre stage, usually women, policy interventions should firstly provide an enabling environment for gender-sensitive value chains for traditional fermented foods. This is similar to other value chains connecting women entrepreneurs to (in)formal markets and surely applies to value chains of traditional fermented foods. Specifically, this would imply a focus on technological, institutional and organizational innovations conducive to acknowledge and support women's role in food security and to their empowerment.

Traditional fermentation originates as (women dominated) household activity and lifting production and sales from household level could cause in fact a shift from the predominantly female producers in households to male-biased smallscale production systems, potentially putting current producers/sellers out of business (Materia and Dentoni, 2020; Rampa et al., 2020). Therefore, we argue that a specific focus on fostering and strengthening women entrepreneurship in the traditional fermented food sector is needed for three reasons. Firstly, they are the owners of the local knowledge on traditional processing. Secondly, empowering local 
processors is the most sustainable way of long-term development and food and nutrition security. Thirdly, the gains of economic empowerment of those at the bottom of the pyramid are highest when putting small scale processors at the center stage. Apart from the fact that upscaling at cooperatives may be (most) profitable, the need for special attention for women entrepreneurs is highlighted by many sources, which show that there is a considerable gender gap in entrepreneurial activity worldwide (FAO, 2010, 2015), with significantly more men than women being in the process of starting a business or operating new businesses.

A conscious gender approach will lead to more participation in decision making and will improve the social standing of women as entrepreneurs (FAO, 2010). Women's anecdotes of gaining empowerment and searching emancipation through entrepreneurship tell us of examples of women breaking away from male domination in work and society by means of embarking upon self-employment to change their condition of subordination and inspire other women (Anderson and Obeng, 2017; Materia and Dentoni, 2020; Rindova et al., 2009). This will lead to higher incomes and performances that contribute to women's social and economic empowerment (FAO, 2010; Marshall and Mejia, 2011a).

Further, in order for traditional fermented foods to serve a wider range of consumers in formal markets, policy should enable legislature to formalise current traditional processing practice and put standards based on the use of raw milk and by setting clear guidelines for processing to ensure (microbiological) safety (Capozzi et al., 2017). These standards should also acknowledge issues of gender-based power inequalities and access to choices and resources (Marshall and Mejia, 2011a). This would enhance self-esteem of local processors, acknowledging their provision of a product that adheres to food safety standards and the potential that fermentation can have on enhancing the condition of rural women fully exploited (Reid et al., 2020).

\subsection{Implications of formality of operations: Should upscaling promote traditional fermentation to enter the formal market?}

Although several studies indicate that formalization of informal markets improves livelihoods (Becker, 2004; ILO, 2009), the needs of women have not been taken sufficiently into account by attempts to formalize informal markets either by design or implementation (Vorley, 2013). One-size-fits-all interventions and policies might rather further exclude already marginalized actors, such as women, who are still not granted basic rights, access to and ownership of resources, social security in most of developing countries (FAO, 2010). This suggests lack of evidence-based policy targeting. Some studies have actually showed that where formal employment opportunities are limited, informal markets compensate by means of providing livelihood to the marginalized (Njaya, 2015).

Informal markets might provide low barriers to entry and buffer to women against market recessions (Webb et al., 2009). Moreover, informal market represent often for the marginalised the only way to achieve a livelihood by means of getting an income (Vorley, 2013; Weng, 2015). Research and policy efforts should therefor focus on women's livelihoods and how these can be promoted by strengthening the position of women entrepreneurs in the value chains of traditional fermented foods. The understanding of the relevance informal markets play in challenged contexts and the extent to which formalization should be enhanced. The expectation is that livelihoods could be improved along value chains, both formal and informal, when these are open and sensitive to women. The governance of informal value chains (so for instance the way they are organized) affects prices, quality of supply, entry barriers and opportunities, income generation and distribution, allocation of risks, learning and upgrading. As a consequence, they affect livelihoods outcomes of the actors involved in the value chain (Altenburg, 2006; Mishra and Dey, 2018). Information and knowledge on value chains' governance in informal markets is currently lacking, with the existing literature being criticized for excluding informal markets.

\section{Conclusions}

In this contribution, we elaborated how traditional fermented foods can contribute to food systems transformation focussing on two key food system components. The first is prevention of food losses and enhancement of nutrition, which builds on the functional properties and nutritional characteristics of traditional fermented foods. Fermentation is the transformation of raw materials by microbial activity. Fermentation, including traditional fermentation, adds taste, prolongs shelf-life, and promotes food safety and general health of consumers. While traditional fermented foods are culturally embedded resulting in generally high consumer acceptance, these generic benefits of microbial transformation are currently underutilized, mostly since they have not been formally studied for specific traditional foods and since formal standards for processing are lacking, barring these foods to be included in formal assessments or programs that aim to promote food and nutrition security and livelihoods. This calls for standardization and formalization of traditional processing by setting processing parameters to ensure the final products adhere to food safety parameters and food quality needs. This can allow for upscaling of sustainable and profitable production, as well as specific assessments of nutritional impact and other value addition of these foods. Policy and research should focus both on this formalization and on aspects of upscaling. 
The second component is inclusive entrepreneurship of mostly women producers in the value chains of traditional fermented foods. Fermentation enterprise requires low inputs of resources, is culturally embedded and has been operational for centuries connecting local producers to informal markets. In this contribution we elaborate that promotion of entrepreneurship as part of upscaling of the value chain should focus on current producers, since they own the traditional knowledge and since empowering low-resource processors as entrepreneurs will greatly contribute to long-term promotion of livelihoods. In turn, this will not only ensure better nutrition for a wide range of (low-resource) rural and urban consumers who will have access to high quality nutritious locally embedded fermented foods, it will enhance primary production since there is more consistent and reliable demand for the raw materials such as milk. And finally, women processors will be able to build livelihoods to benefit their family and community, and society at large.

Overall, traditional fermentation, exemplified by the case of Mabisi, Munkoyo, Mahewu and Akpan in Africa, demonstrate how the "hidden middle" between primary production and nutritious and attractive foods for consumers can be bridged through (traditional) food processing (Keding et al., 2013; Reardon and Liverpool-Tasie, 2021). Many traditional fermented foods exist around the world that link primary production to nutritious foods, which offer potential for entrepreneurship of local processors, (gender sensitive) value chains to be built and food and nutrition security to be locally promoted. This should be taken into account when developing policy and research agendas to promote food and nutrition security building on the development of livelihoods for local small-holder farmers, processors and consumers in both urban and rural settings.

\section{Appendix. Description of three focal traditional fermented foods, Mabisi, Mahewu and Akpan}

\section{A. Milk-based fermented food from Zambia: Mabisi}

Mabisi is based on milk. It is made from raw milk that is fermented in a calabash or plastic container of 5 to $20 \quad 1$ to allow spontaneous fermentation at ambient temperatures. After about two days of incubation, a relatively firm, slightly sour, non-alcoholic product is formed that is consumed at home and sold at local markets as an energising and refreshing beverage. It is also consumed with the staple maize-meal thick porridge (Nshima). Mabisi has a perceived shelf-life of up to 10 days at ambient temperatures. Producers of Mabisi are almost exclusively women, who process for their household and also sell the product at local markets, generating a livelihood for themselves and their families. Men, women as well as children from a very young age consume it almost daily in rural areas. Production is in rural areas, at present the product fails to reach larger urban centres and urban consumers. To upscale production from household level to SME level both technological and business development advances are needed. Products based on raw milk are currently not allowed for formal sales, however, previous work has shown that Mabisi is safe for consumption due to low $\mathrm{pH}$. Other work has shown that health benefits exist through the modulation of gut microbiota towards a healthier composition after exposure to microbial communities from Mabisi.

A
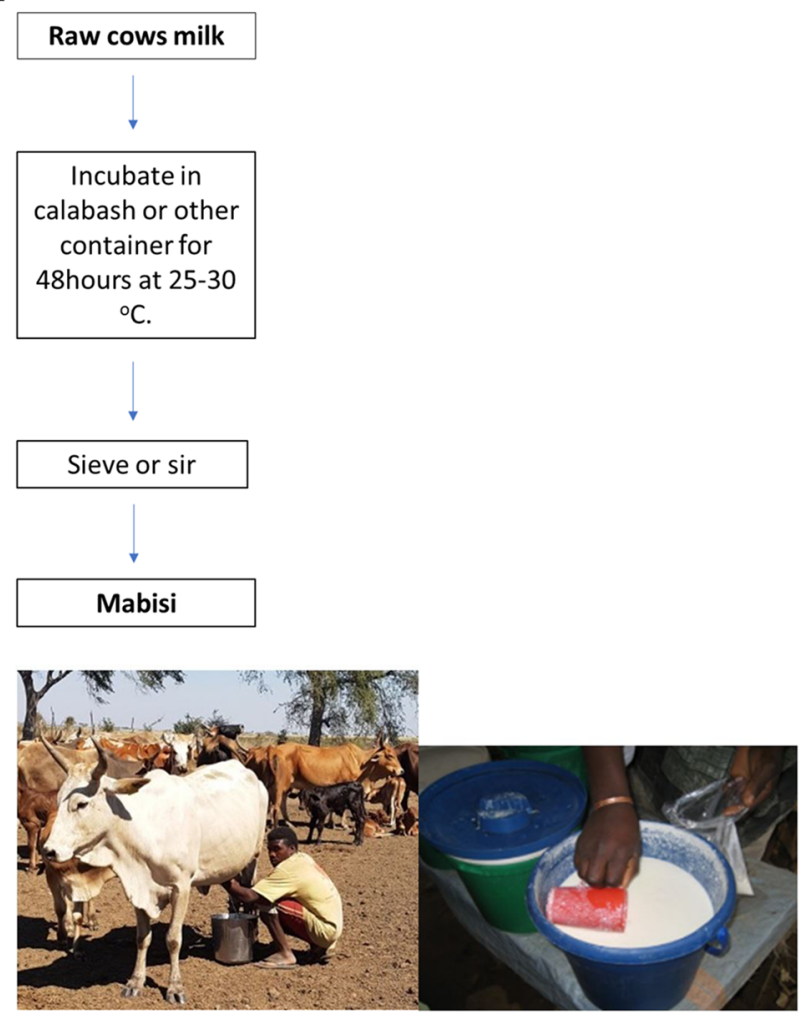

\section{B. Cereal-based fermented food from Benin: Akpan}

Akpan is a traditional Beninese non-alcoholic fermented cereal-based beverage, locally also known as a vegetable yoghurt. It is made from fermented cereal (ogi) where depending on the taste of the consumer, milk and sugar are added to taste at the end of fermentation. The product is consumed in urban as well as rural areas in the country. The product has received already substantial attention from researchers who have defined detailed protocols for traditional processing (Sacca et al., 2012). Different types of Akpan exist due to slight variations in processing and in the types of cereal used. A recent study on sensory profiling indicated that the consumer preferences differed for the different Akpan variants which are around 
(Akissoé et al., 2015). Akpan originates from rural areas and is now also produced in larger cities, close to poor urban consumers who are the main consumers at the moment. The raw materials are relatively easy to get by in the cities. Research has been done in the past 15 years on the product by the University of Abomey-Calavi and others as part of the AFTER project (EU-FP7), labelling and standard processing have been suggested. Some small scale processors have now developed modern packaging and labelling. Production is a purely women's activity. Sales and related activities do sometimes involve men. A technological hurdle is to generate a version with extended shelf life and how to implement mechanisation of some steps in processing is needed as first steps to upscaling in urban areas. Given the small-scale production, these machines are not affordable to individual processors. Some sort of associations between processors could be formed to facilitate upscaling. This would also give them a voice towards supermarkets and other outlets to sell their products.

Two variants of Akpan, each made with different fermentable substrates. Picture from: Sacca, Akissoe, Dalode, Anihouvi, Hounhouigan and Mestres. 2012. Food Chain 2: 207-220. Poster FP7 245-025 AFTER project.

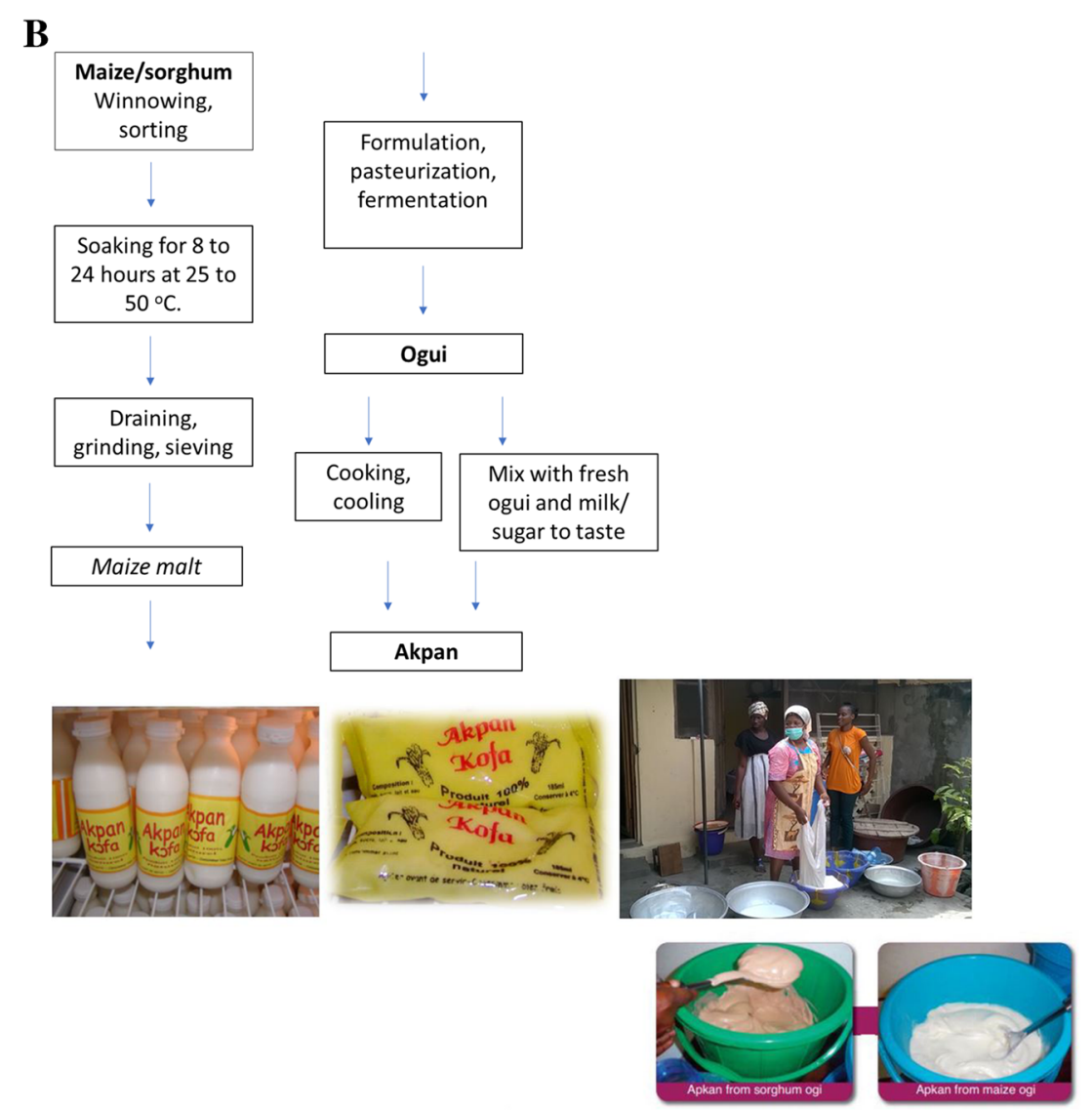

\section{Mixed cereal-based fermented beverage from Zimbabwe: Mahewu}

Mahewu is a mixed maize/millet cereal-based fermented nonalcoholic beverage. Many versions of such cereal based fermented beverages exist in southern Africa and Mahewu from Zimbabwe is usually produced with maize as main fermentable substrate. Processing of Mahewu has been researched and microbial profiles and suggestions for processing optimization have been suggested. Lactic acid bacteria are dominating the microbial community involved in the spontaneous fermentation of Mahewu. Besides production at household level, also commercial variants of Mahewu are being produced and quite well-known in Zimbabwe but these products are often highly simplified and lack a fermentation step or do not contain complex microbial starters, which does not match consumer's expectations of a traditional product. Obviously, the latter products are often consumed in urban regions while homemade Mahewu is still available in rural Zimbabwe. In general, Mahewu from Zimbabwe is low in 
nutrients and the use of provitamin A ( $\beta$-carotene) enriched maize (also known as orange maize) as fermentable substrate has been suggested as a means to promote nutritional content of the beverage. Traditional Mahewu is promoted for schoolfeeding programs in rural areas. Production of traditional Mahewu takes place in rural areas and could be done as well in urban areas close to focal consumers.

C

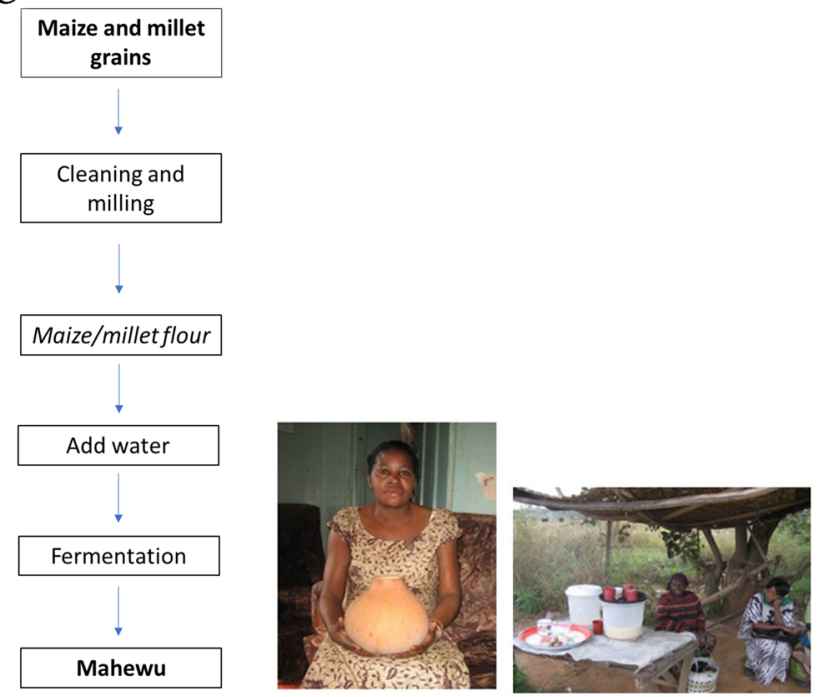

Acknowledgements The insight generated in this contribution emerged from numerous discussions and reflections in the context of a series of projects. Collaborators have greatly contributed to the ideas presented here. They are (graduated) PhD candidates Bernard Moonga, Sydney Phiri, Anneloes Groenenboom, Justin Chileshe, as well as Ardinesh Kambanje, Robert Nhlane, Blandine Ekpodilè, Thelma Sikombe, Betty Madzora, Sakile Kudita, Carole Sanya, Alanna Leale, Shepherd Nehanda, Mubonda Kalumbilo, Taonga Chirwa-Moonga and Murambiwa Nyati. Other collaborators in Africa include John Shindano, Nachimuka Cheepa, Yvonne Mtumbi, Ray Handema, Juliet Mubaiwa, Grace Ngorora, Yann Madodé and Joseph Hounhouigan. Wageningen collaborators include Anna Alekseeva, Elise Talsma, Bas Zwaan, Vincenzo Fogliano, Gerlinde De Deyn and Wilfred Dolfsma. Special thanks to Ruerd Ruben for encouragement on the structuring of this contribution and to Leslie Lipper, Rob Nout and other anonymous reviewers for their helpful and constructive feedback.

Funding This work has been funded by grants under an Research Development Programme Fellowship of the University of Ottawa, a Marie Curie Fellowship from the European Union, an integrated research project grant from NWO-WOTRO Grand Challenges Programme and INREF Wageningen Interdisciplinary Research and Education Fund.

This article is derived from [chapter ... or section ...] of the Rural Development Report [full reference]".

\section{Declarations}

Conflict of interest The authors declare that no conflict of interest nor any competing interests exist.

Open Access This article is licensed under a Creative Commons Attribution 4.0 International License, which permits use, sharing, adaptation, distribution and reproduction in any medium or format, as long as you give appropriate credit to the original author(s) and the source, provide a link to the Creative Commons licence, and indicate if changes were made. The images or other third party material in this article are included in the article's Creative Commons licence, unless indicated otherwise in a credit line to the material. If material is not included in the article's Creative Commons licence and your intended use is not permitted by statutory regulation or exceeds the permitted use, you will need to obtain permission directly from the copyright holder. To view a copy of this licence, visit http://creativecommons.org/licenses/by/4.0/.

\section{References}

Altenburg, T. (2006). Governance patterns in value chains and their development impact. The European Journal of Development Research, 18, 498-521.

Anderson, A. R., \& Obeng, B. A. (2017). Enterprise as socially situated in a rural poor fishing community. Journal of Rural Studies, 49, 23 31.

Anukam, K. C., \& Reid, G. (2009). African traditional fermented foods and probiotics. Journal of Medicinal Food, 12, 1177-1184.

Arslan, A., Berkum, S.V., et al, , 2020. IFAD RDR 2021 - Framework for the Analysis and Assessment of Food Systems Transformations.

Aworh, O.C., 2008. The role of traditional food processing technologies in national development: The west African experience., in: Robertson, G.L., Lupien, J.R. (Eds.), using food science and technology to improve nutrition and promote National Development. International Union of Food Science and Technology (IUFoST).

Battcock, M., Azam-Ali, S., 1998a. Fermented fruits and vegetables. A global perspective. United Nations Rome Fao agricultural services bulletin, 10-15.

Battcock, M., \& Azam-Ali, S. (1998b). Fermented fruits and vegetables. FAO, Rome: A global perspective.

Becker, K.F., 2004. The informal economy: Fact finding study, https:// www.eldis.org/document/A15832. Swedish International Development Cooperation Agency (SIDA), Stockholm.

Bell, V., Ferrão, J., \& Fernandes, T. (2017). Nutritional Guidelines and Fermented Food Frameworks. Foods, 6.

Berkum, S.v., Dengerink, J., \& Ruben, R. (2018). The food systems approach: Sustainable solutions for a sufficient supply of healthy food. The Hague: Wageningen Economic Research.

Busse, M., \& Siebert, R. (2018). The role of consumers in food innovation processes. European Journal of Innovation Management, 21, $20-43$.

Butler, S., \& O'Dwyer, J. P. (2018). Stability criteria for complex microbial communities. Nature Communications, 9, 2970.

Capozzi, V., Fragasso, M., Romaniello, R., Berbegal, C., Russo, P., \& Spano, G. (2017). Spontaneous food fermentations and potential risks for human health. Fermentation, 3, 49.

Carbonetto, B., Ramsayer, J., Nidelet, T., Legrand, J., Sicard, D., 2018. Bakery yeasts, a new model for studies in ecology and evolution. Yeast (Chichester, England) 35.

Chadare, F. J., Fanou Fogny, N., Madode, Y. E., Ayosso, J. O. G., Honfo, S. H., Kayodé, F. P. P., Linnemann, A. R., \& Hounhouigan, D. J. (2018). Local agro-ecological condition-based food resources to promote infant food security: A case study from Benin. Food Security, 10, 1013-1031.

Chileshe, J. (2019). Nutrition, health and microbial ecology of traditional fermented foods in Zambia. Wageningen: Wageningen University.

Chileshe, J., Talsma, E. F., Schoustra, S. E., Borgonjen-van den Berg, K. J., Handema, R., Zwaan, B. J., \& Brouwer, I. D. (2020a). Potential contribution of cereal and milk based fermented foods to dietary 
nutrient intake of 1-5 years old children in central province in Zambia. PLoS One, 15, e0232824.

Chileshe, J., van den Heuvel, J., Handema, R., Zwaan, B. J., Talsma, E. F., \& Schoustra, S. (2020b). Nutritional composition and microbial communities of two non-alcoholic traditional fermented beverages from Zambia: A study of Mabisi and Munkoyo. Nutrients, 12, 1628.

Dohmwirth, C., \& Hanisch, M. (2019). Women 's active participation and gender homogeneity: Evidence from the south Indian dairy cooperative sector. Journal of Rural Studies, 72, 125-135.

Egounlety, M., Aworh, O. C., Akingbala, J. O., Houben, J. H., \& Nago, M. C. (2002). Nutritional and sensory evaluation of Tempe-fortified maize-based weaning foods. International Journal of Food Sciences and Nutrition, 53, 15-27.

Elberi, A., \& Lee, M. (2011). The role of women producer organizations in agricultural value chains. Practical lessons from Africa to India. Rome: FAO.

Erkus, O., de Jager, V. C., Spus, M., van Alen-Boerrigter, I. J., van Rijswijck, I. M., Hazelwood, L., Janssen, P. W., van Hijum, S. A., Kleerebezem, M., \& EJ., S. (2013). Multifactorial diversity sustains microbial community stability. ISME Journal, 7, 2126-2136.

FAO, 2010. Rural women's entrepreneurship is "good business"!. Gender and Rural Employment Policy Brief \#3, Rome.

FAO, 2015. Running Out of Time: The reduction of women's work burden in agricultural production., in: http://www.fao.org/3/ai4741e.pdf. (Ed.), Rome.

FAO, 2018. Employment, work and time use in agricultural contexts: what data do we need for gender analysis?, http://www.fao.org/3/ i8845en/I8845EN.pdf Rome.

FAO, \& WHO. (1996). Fermentation : Assessment and research : Report of a joint FAO/WHO workshop on fermentation as a household technology to improve food safety, in collaboration with the Department of Health, Republic of South Africa, Pretoria, South Africa, 11-15 December 1995. Geneva: World Health Organization.

Fellows, P., \& Hilmi, M. (2011). Selling street and snack foods. Rome: FOA.

GlobalPanel, 2016. Food systems and diets: Facing the challenges of the 21st century., in: Nutrition, G.P.o.A.a.F.S.f. (Ed.), http://glopan.org/ sites/default/files/ForesightReport.pdf, London, UK.

Hesseltine, C., \& Wang, H. L. (1967). Traditional fermented foods. Biotechnology and Bioengineering, 9, 275-288.

HLPE, 2017. Nutrition and food systems, A report by the High Level Panel of Experts on Food Security and Nutrition of the Committee on World Food Security, Rome.

Holzapfel, W. H. (2002). Appropriate starter culture technologies for small-scale fermentation in developing countries. International Journal of Food Microbiology, 75, 197-212.

Ibnouf, F. O. (2011). Challenges and possibilities for achieving household food security in the Western Sudan region: The role of female farmers. Food Security, 3, 215-231.

IFAD, 2019. Brief on gender and social inclusion, East and Southern Africa. https://www.ifad.org/documents/38714170/41801153/ genderbrief_esa.pdf/19b405a0-2a72-de2d-acca-04a42ea44274.

ILO, 2009. The informal economy in Africa: Promoting transition to formality: Challenges and strategies, in: Employment Policy Department, E.S.a.S.P.S.-I.L.O. (Ed.), 978-92-2-122969-3[ISBN]. https://www.ilo.org/emppolicy/pubs/WCMS_127814/lang\%2D\% 2Den/index.htm.

ILO, 2018. World Employment and Social Outlook: Trends for Women 2018 - Global snapshot, https://www.ilo.org/global/research/globalreports/weso/trends-for-women2018/WCMS_619577/lang\%2D\% 2Den/index.htm.

Joyce, A., Paquin, R., \& Pigneur, Y. (2015). The triple layered busienss model canvas as a tool to design of sustainable buisness models, ARTEM organizational creativity international conference. France: Nancy.
Kadirvel, G., Banerjee, B. B., Meitei, S., Doley, S., Sen, A., \& Muthukumar, M. (2018). Market potential and opportunities for commercialization of traditional meat products in north East Hill region of India. Vet World, 11, 118-124.

Katz, S.E., 2016. Wild fermentation: The flavor, nutrition, and craft of live-culture foods. Chelsea Green Publishing.

Keding, G. B., Schneider, K., \& Jordan, I. (2013). Production and processing of foods as core aspects of nutrition-sensitive agriculture and sustainable diets. Food Security, 5, 825-846.

Kort, R., \& Sybesma, W. (2012). Probiotics for every body. Trends in Biotechnology, 30, 613-615.

Kuhnlein, H., Erasmus, B., Spigelski, D., Food, Nations, A, 2009. Indigenous peoples ' food systems: the many dimensions of culture, diversity and environment for nutrition and health.

Linnemann, A. R., Benner, M., Verkerk, R., \& Van Boekel, M. A. J. S. (2006). Consumer-driven food product development. Trends in Food Science and Technology, 17, 184-190.

Madode, Y.E., Hounhouigan, J.D., Mestres, C., 2005. Upgrading of traditional food processing: Improvement of \#akpan\#, a traditional yoghourt-like maize-based beverage from Benin, in: NLD, E.F.-., Csic, E.S.P., Universidad Politecnica de Valencia, E.S.P. (Eds.), Innovations in Traditional Foods Conference (IntraFood 2005). CIRAD, Valence, Espagne, p. 2 p.

Marco, M. L., Heeney, D., Binda, S., Cifelli, C. J., Cotter, P. D., Foligné, B., Gänzle, M., Kort, R., Pasin, G., Pihlanto, A., Smid, E. J., \& Hutkins, R. (2017). Health benefits of fermented foods: Microbiota and beyond. Current Opinion in Biotechnology, 44, 94-102.

Marshall, E., \& Mejia, D. (2011a). Traditional fermented food and beverages for improed livelihoods (p. 86). Rome: FAO diversification booklet. FAO.

Marshall, E., \& Mejia, D. (2011b). Traditional fermented food and beverages for improved livelihoods (p. 86). Rome: FAO diversification booklet. FAO.

Materia, V. C., \& Dentoni, D. (2020). De bijdrage van ondernemerschap van vrouwen en jongeren aan voedselzekerheid: een verhaal van empowerment en emancipatie. In I. De Zwarte \& J. Candel (Eds.), Tien milhjard monden. Amsterdam: Prometheus.

Materia, V.C., Linnemann, A.R., Smid, E.J., Schoustra, S., 2021. Upscaling of traditional fermented foods to build value chains and to promote women entrepreneurship, IFAD rural development report - background paper, To be published.

Mishra, P. K., \& Dey, K. (2018). Governance of agricultural value chains: Coordination, control and safeguarding. Journal of Rural Studies, 64, 135-147.

Moonga, H. B. (2019). Product optimization of Zambian traditionally fermented milk - mabisi. Wageningen: Wageningen University.

Moonga, H. B., Phiri, S., Schoustra, S. E., Chileshe, J., Chirwa-Moonga, T., \& Shindano, J. (2020a). The Munkoyo root: Traditional uses, biochemistry, fermentation, and potential cultivation (pp. 81-99). African Natural Plant Products, Volume III: Discoveries and Innovations in Chemistry, Bioactivity, and Applications. American Chemical Society.

Moonga, H. B., Schoustra, S. E., Linnemann, A. R., Kuntashula, E., Shindano, J., \& Smid, E. J. (2019). The art of mabisi production: A traditional fermented milk. PLoS One, 14, e0213541.

Moonga, H. B., Schoustra, S. E., van den Heuvel, J., Linnemann, A. R., Samad, M. S., Shindano, J., \& Smid, E. J. (2020b). Composition and diversity of natural bacterial communities in mabisi, a traditionally fermented milk. Frontiers in Microbiology, 11, 1816.

Morrison, D. J., \& Preston, T. (2016). Formation of short chain fatty acids by the gut microbiota and their impact on human metabolism. Gut Microbes, 7, 189-200.

Mtumbi-Mwansa, Y. (2021). A business case for Mabisi processing, sales and entrepreneurship in Zambia. Lusaka: AgriEn Zambia.

Mwambi, M., Bijman, J., \& Mshenga, P. (2020a). Which type of producer organization is (more) inclusive? Dynamics of farmers' 
membership and participation in the decision-making process. Annals of Public and Cooperative Economics, 91, 213-236.

Mwambi, M., Bijman, J., Mshenga, P., \& Oosting, S. (2020b). Adoption of food safety measures: The role of bargaining and processing producer organizations. NJAS - Wageningen Journal of Life Sciences, 92, 100337.

Njaya, T. (2015). Informal sector, panacea to the high unemployment in Zimbabwe? Case of informal sector Enterprises of Harare Metropolitan. International Journal of Research in Humanities and Social Studies, 2, 97-106.

Nout, M. J. R., Darkar, P. K., \& Beuchat, L. R. (2007). Indigenous fermented foods. In M. P. Doyle \& L. R. Beuchat (Eds.), Food microbiology: Fundamentals and Frontiers (Third ed., pp. 817835). Washingon DC: ASM Press.

Nout, M.J.R., De Vos, W.M., Zwietering, M.H., 2005. Food fermentation. Wageningen Academic Publishers.

Olagunju, Y.A., Oluwale, B.A., Ilori, M.O., 2020. Characterization of production technologies employed by selected small and medium scale enterprises in the food and beverage industry in southwestern NIGERIA. African Journal of Science Policy and Innovation Management 1, 93-102.

Patel, K., Guenther, D., Wiebe, K., \& Seburn, R.-A. (2014). Promoting food security and livelihoods for urban poor through the informal sector: A case study of street food vendors in Madurai, Tamil Nadu, India. Food Security, 6, 861-878.

Phiri, S. (2019). Spontaneous fermentation of Munkoyo: A cereal-based beverage in Zambia. Wageningen: Wageningen University.

Phiri, S., Schoustra, S. E., van den Heuvel, J., Smid, E. J., Shindano, J., \& Linnemann, A. (2019). Fermented cereal-based Munkoyo beverage: Processing practices, microbial diversity and aroma compounds. PLoS One, 14, e0223501.

Project-team, 2017. Zambia dairy association and various dairy cooperatives. University of Zambia project team.

Pswarayi, F., \& Gänzle, M. G. (2019). Composition and origin of the fermentation microbiota of Mahewu, a Zimbabwean fermented cereal beverage. Applied and Environmental Microbiology, 85, e03130-e03118.

Rampa, F., Lammers, E., Linnemann, A., Schoustra, S., \& de Winter, D. (2020). Pathways to improved food and nutrition security of the poor: The promise of African indigenous foods and technologies. The Hague, The Netherlands: NWO-WOTRO synthesis study.

Reardon, T., Liverpool-Tasie, S., 2021. The evolution of the midstream the hidden middle - in inclusive agrifood systems transformation. IFAD development report corner stone paper.

Reid, G., Sybesma, W., Matovu, W., Onyango, A., Westerik, N., \& Kort, R. (2020). Empowering women through probiotic fermented food in East Africa. Journal of Global Health, 10, 010330.

Rindova, V., Barry, D., \& Ketchen, D. J. (2009). Entrepreneuring as emancipation. Academy of Management Review, 34, 477-491.

Robson, G., \& Gallagher, C. (1993). The job creation effects of small and large firm interaction. International Small Business Journal, 12, 23-37.

Schoustra, S.E., Groenenboom, A., Moonga, H., Phiri, S., Chileshe, J., Shindano, J., Smid, E.J., Linnemann, A.R., Zwaan, B., 2018. Zambian traditional fermented foods project page GCP-1. . http:// knowledge4food.net/research-project/gcp1-zambian-traditionalfermented-foods/, Published by Food and Business Knowledge Platform.

Smid, E. J., \& Hugenholtz, J. (2010). Functional genomics for food fermentation processes. Annual Review in Food Science and Technology, 1, 497-519.
Taiwo, K. A., Oladepo, O. W., Ilori, M. O., \& Akanbi, C. T. (2002). A study on the NIGERIAN food industry and the impact of technological changes on the small-scale food enterprises. Food Reviews International, 18, 243-261.

Tamang, J. P., Cotter, P. D., Endo, A., Han, N. S., Kort, R., Liu, S. Q., Mayo, B., Westerik, N., \& Hutkins, R. (2020). Fermented foods in a global age: East meets west. Comprehensive Reviews in Food Science and Food Safety, 19, 184-217.

Thierry, A., Pogacic, T., Weber, M., Lortal, S., 2015. Production of flavor compounds by lactic acid Bacteria in fermented foods, biotechnology of lactic acid Bacteria, pp. 314-340.

UNEP, 2016. Food systems and natural resources. A report of the working group on food Systems of the International Resource Panel, in: Westhoek, H., Ingram J., Van Berkum, S., Özay, L., M., H. (Eds.).

Van de Ven, L., 2018. Consumer perspective on Mabisi. MSc Thesis Wageningen University http://knowledge4food.net/consumerperspective-on-traditional-mabisi/

Van der Zon, C., 2019. Microbial safety of Mabisi. MSc thesis Wageningen University.

Vorley, B., 2013. Meeting small-scale farmers in their markets: Understanding and improving the institutions and governance of informal Agrifood trade. International Institute for Environment and Development (IIED).

Waltz, C. L. (2010). Local food systems: Background and issues. Incorporated: Nova Science Publishers.

Webb, J. W., Tihanyi, L., Ireland, R. D., \& Sirmon, D. G. (2009). You say illegal, I say legitimate: Entrepreneurship in the informal economy. Academy of Management Review, 34, 492-510.

Weng, X., 2015. The rural informal economy: Understanding drivers and livelihood impacts in agriculture, timber and mining. IEED Working Paper.

Wolkers-Rooijackers, J. C. M., Endika, M. F., \& Smid, E. J. (2018) Enhancing vitamin B12 in lupin tempeh by in situ fortification. LWT, 96, 513-518.

WorldBank. (2011). What would it take for Zambia's beef and dairy industries to achieve their potential? Davers, MA USA: World Bank.

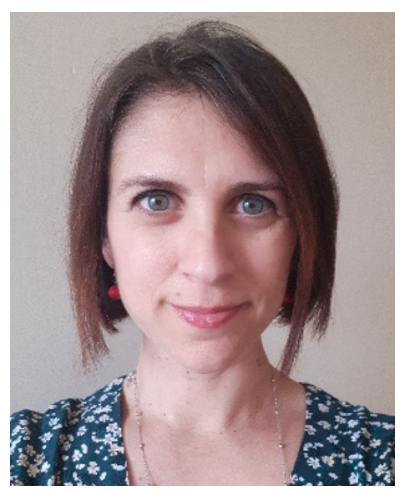

Valentina C Materia . She holds a $\mathrm{PhD}$ in Economics, is Assistant Professor in Innovation and Entrepreneurship at the Business Management and Organisation group, Department of Social Science of Wageningen University and Research, The Netherlands. As applied economist who developed an interest for innovation as connected to organization theories, institutional economics, business management and entrepreneurship, Valentina's research focuses on: aspects of governance in the transition towards sustainable food systems; women entrepreneurship in challenging environments; value chains analysis and design; dynamics and organization of innovation in agri-food supply chains. For her purposes she applies quantitative research methods but also more inductive approaches to her research. Her work has been published in journals such as Food Policy, Journal of Agricultural Economics, R \& D Management, European Journal of Development Research, British Food Journal among others. 


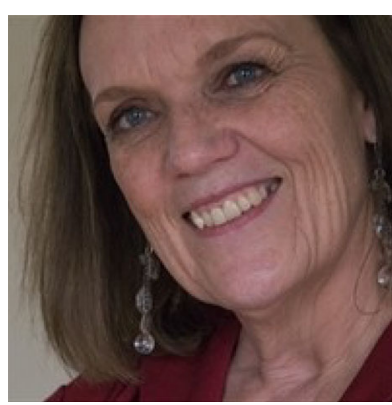

Anita R. Linnemann holds a position as associate professor at Food Quality and Design, Wageningen University, the Netherlands. The ambition of her research is the development of food technological solutions to enhance nutrition security in developing countries, in particular at the basis-of-the-pyramid in sub-Saharan Africa. To this end, she applies a consumer-oriented perspective in combination with local food resources and tailormade food technological practices. Moreover, she takes the entire food production chain into account to ensure that the food system becomes as sustainable as possible.

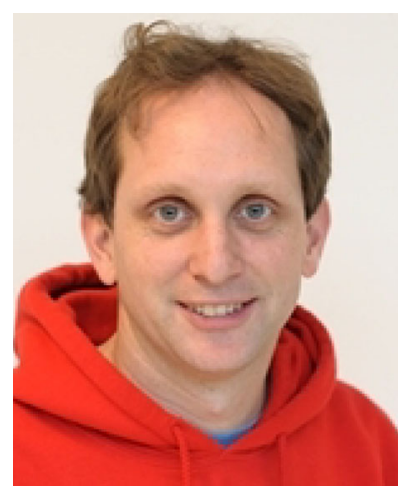

Sijmen Schoustra . Sijmen Schoustra is cross-appointed between the University of Zambia and Wageningen University in the Netherlands. Sijmen's main expertise is in microbial ecology and evolution, use of experimental evolution to study how organisms adapt to new challenges and into stable eco-systems. In the past 10 years, he has developed traditional fermented foods as a model system to study questions surrounding short and long term ecosystem dynamics by focussing on the natural bacterial communities present in these products and has been the coordinator of two long-term interdisciplinary projects on the topic of traditional fermentation.

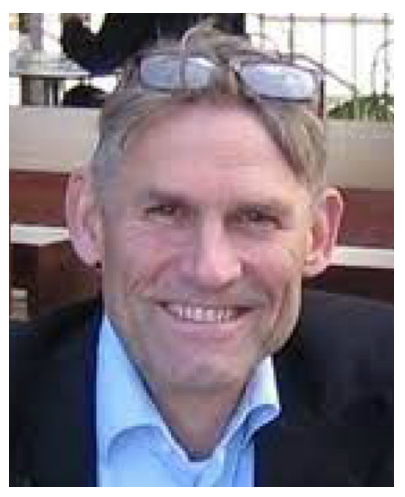

Eddy J Smid . His work focuses on non-GMO strategies to steer and control starter culture functionality in traditional and industrial fermentation. Biodiversity mining, population dynamics and adaptive evolution strategies are being applied to achieve the desired culture properties which produce fermented food products with novel functionalities. His has broad expertise in food microbiology, microbial ecology and biotechnology. 